\title{
The impact of soil texture on the selection of nesting sites by the Malachite Kingfisher (Alcedinidae: Alcedo cristata Pallas 1764)
}

\author{
R Kisasa Kafutshi ${ }^{1,2}$ and J Aloni Komanda ${ }^{2}$ \\ ${ }^{1}$ Faculty of Science, University of Liège, 27 Rectorat Street, Sart Tilman, 4000 Liège, Belgium \\ ${ }^{2}$ Faculty of Science, University of Kinshasa, PO Box 190, Kinshasa XI, Democratic Republic of Congo \\ *Corresponding author, e-mail: bob_kisasa@yahoo.fr
}

The first granulometrical analysis of soil samples from nesting banks of the Malachite Kingfisher Alcedo cristata is reported. In total 56 samples from the Kinshasa area were analysed. Three standardised particle size fractions were determined in all groups of samples (percentage of sand, clay and silt). Mean particle percentage of soil samples from banks occupied by Malachite Kingfishers averaged $10.8 \pm 6.1$ of silt, $11.6 \pm 6.5$ of clay and $81.4 \pm 11.4$ of sand. A significant difference was found in the proportion of clay between banks with and without kingfisher nests. The results of the present study hence suggest that, as has been documented in other burrowing bird species, soil texture determines the selection of nesting sites in the Malachite Kingfisher. Our results indicate that even a slight difference in the proportion of clay can substantially affect the suitability of banks for the establishment of nests. In fact, burrowing birds must find suitable soils whose structure allows for a good compromise between stability and hardness to dig out, which poses an energy challenge just before the breeding season.

\section{Introduction}

Soil texture is a factor of prime importance controlling the distribution, frequency and reproductive success of burrowing birds (Heneberg 2004). For instance, the soil of the banks used by Bee-eaters Merops apiaster contains a load of sand particles between 28.0 and $9.2 \mu \mathrm{m}$ that is 20 times higher than that of the banks used by Sand Martins Riparia riparia (Henerberg 2004, Yuan et al. 2006). In particular, soil grain size determines the depth of the tunnels, which in turn correlates with the reproductive success (Heneberg 2009). In Sand Martins and the European Kingfisher Alcedo atthis, Heneberg (2001, 2004) demonstrated that the highest rates of reproductive success are achieved in areas with a soil texture of $<900 \mu \mathrm{m}$ and $40000 \mu \mathrm{m}$, respectively.

The impact of this factor has, however, been the focus of a strikingly low number of studies, with a severe lack in tropical areas. In the Kinshasa area, the dense hydrographic network of rivers with steep banks, large prey availability, and fairly slow runoff, appears at first sight highly suitable for burrowing birds. Yet, only an extremely low number of sites actually hosts nesting populations of the Malachite Kingfisher Alcedo cristata. In this paper, we compare soil granulometry in river banks with and without nesting colonies to determine whether this factor controls the selection of nesting sites and document the range of soil conditions that are suitable for nesting in that species.

\section{Material and methods}

The Kinshasa area $\left(9.965 \mathrm{~km}^{2}\right)$ was surveyed from 2004 to 2009 for the presence of nesting sites. In total, 56 sites exhibiting appropriate habitat conditions for the Malachite Kingfisher, including presence of perches (Monadjem and
Owen-Smith 1994, Siikamäki 1998, Bonnington et al. 2007), prey availability (Woodall 1991, Libois and Laudelout 2004), water with low turbidity levels (Douthwaite 1976, Eriksson 1985, Martin 1987) and slow runoff (Peris and Rodriguez 1996) were surveyed. A soil sample of $500 \mathrm{~g}$ was collected at each site for subsequent analysis of granulometry. After the removing of organic matter following a treatment with $30 \% \mathrm{H}_{2} \mathrm{O}_{2} 0.01 \mathrm{~N} \mathrm{HCl}$, the sand fraction was separated using a dry sieve with a $63 \mu \mathrm{m}$ grain size and further characterised using a grain size of 100, 250, 500, 1000 and $2000 \mu \mathrm{m}$. The silt and clay fractions were quantified using Köhn's method. The different fractions were classified following the USDA's textural triangle (Richer de Forges et al. 2008).

Differences in granulometry were sought between sites with and without evidence of nesting using Student's $t$-test.

\section{Results}

Of the 56 banks surveyed, 68\% were used at least once by the Malachite Kingfisher between 2004 and 2009. The granulometry of bank soils with and without evidence for nesting activity is presented in Appendix 1 and summarised in Table I.

The $t$ test revealed a significant difference in the proportion of clay between banks with and without kingfisher nests $(t=3.27, p<0.05)$. The proportions of sand and loess were, by contrast, not significantly different.

\section{Discussion}

Previous studies on the selection of nesting sites in the Malachite Kingfisher emphasised the importance of perch 
Table 1: Granulometry of banks soils with $(n=23)$ and without $(n=23)$ evidence for nesting in the Malachite Kingfisher in the Kinshasa area

\begin{tabular}{|c|c|c|c|c|c|c|}
\hline \multirow{2}{*}{ Particle content (\%) } & \multicolumn{3}{|c|}{ Occupied banks } & \multicolumn{3}{|c|}{ Unoccupied banks } \\
\hline & Sand & Silt & Clay & Sand & Silt & Clay \\
\hline Mean \pm SD & $81.4 \pm 11.4$ & $10.8 \pm 6.1$ & $7.5 \pm 6.6$ & $78.9 \pm 13$ & $8.5 \pm 5.6$ & $11.6 \pm 6.5$ \\
\hline Minimum & 66.2 & 4.9 & 2.1 & 56.9 & 3.1 & 2.7 \\
\hline Maximum & 92.6 & 18.8 & 18.9 & 92.4 & 14.7 & 18.7 \\
\hline
\end{tabular}

availability (Monadjemand Owen-Smith 1994, Siikamäki 1998, Bonnington et al. 2007), water depth and transparency (Douthwaite 1976, Eriksson 1985, Martin 1987), prey availability and disturbance levels (Woodall 1991, Libois and Laudelout 2004, Imboma and Nalianya 2007). The results of the present study further suggest that, as has been documented in other burrowing bird species (Heneberg 2009), soil texture determines the selection of nesting sites in the Malachite Kingfisher. Our results indicate that even a slight difference in the proportion of clay can substantially affect the suitability of banks for the establishment of nests. In fact, burrowing birds must find suitable soils whose structure allows for a good compromise between hardness and stability (Gilroy et al. 2008).

On the one hand, a sufficient clay content must be present to ensure the stability of the nest and decrease the risk of collapsing (Heneberg 2004). Since the depth of the nest regulates the rates of nesting success, soil texture and structure are, hence, factors of prime importance in the ecology of burrowing birds (Heneberg 2001). In fact, a significant correlation was found between the depth of the nest and soil texture in Sand Martins. Soils with a grain size of $<900 \mu \mathrm{m}$ hosted deeper nests than soils with a coarser texture. The European Kingfisher Alcedo atthis is restricted to sites wherein soil texture is such that grain size never exceeds $40000 \mu \mathrm{m}$ (Heneberg 2004). In the Kinshasa area, it seems that a level of $7 \%$ clay, in conjunction with an average silt content of $10 \%$, is sufficient to prevent nests from collapsing.

On the other hand, a soil that is hard to dig out will pose an energy challenge just before the breeding season. Soil type is predominant among the environmental factors affecting the costs and benefits of nesting strategies of burrowing birds (Heneberg 2004). In the first papers dealing with the relationship between nesting of burrowing birds and soil properties, Petersen (1955) and Sandmann-Funke (1972) demonstrated that if the soil contains too much clay, it is too hard to allow for digging. Several reports dealt with the clay content and stated that the clay content should generally be $<10 \%$ (Petersen 1955). Information on the energy cost of reproduction in the Malachite Kingfisher are lacking. Similar studies in the owl Tyto alba showed for instance that body size of the female increases $20 \mathrm{~d}$ before egg-laying, whereas egg development in the ovary starts only $15 \mathrm{~d}$ before that period (Blondel et al. 1999, Durant 2000). In order to avoid any deficit, birds must hence adjust their energy balance, taking the cost of the different activities and food availability into account (Ricklefs 1968, Durant 2000). Different nesting bird species in sympatry thus partition the environment along pedological gradients. For instance, Bee-eaters and Sand Martins establish their nests in banks with contrasting soil texture to avoid competition (Heneberg 2009). The hypothesis that different sympatric kingfishers also partition the environment depending on soil texture and their energy balance during the breeding season is currently explored in the context of ongoing research in African Pygmy Kingfisher Ceyx pictus, Woodland Kingfisher Halcyon senegalensis and Pied Kingfisher Ceryle rudis from the Kinshasa area.

Acknowledgements - We are grateful to Dr Alain Vaderpoorten. His comments were relevant and appreciated for presentation of my results.

\section{References}

Blondel J, Dias PC, Perret P, Maitre M, Lambrechts MM. 1999. Selection-based biodiversity a small spatial scale in a lowdispersing insular bird. Science 285: 1399-1402.

Bonnington C, Weaver D, Fanning E. 2007. The habitat preference of four kingfisher species along a branch of the Kilombero River, southern Tanzania. African Journal of Ecology 46: 424-427.

Douthwaite RJ. 1976. Fishing techniques and foods of the pied kingfisher on Lake Victoria in Uganda. Ostrich 47: 153-160.

Durant J. 2000. Energétique de la reproduction chez la chouette effraie (Tyto alba). Thèse, Université Louis Pasteur, Strasbourg, France.

Eriksson MOG. 1985. Prey detectability for fish-eating birds in relation to fish density and water transparency. Ornis Scandinavica 16: $1-7$.

Gilroy JJ, Anderson GQ, Grice PV, Vickery JA, Bray I, Nicholas Watts P, Sutherland WJ. 2008. Could soil degradation contribute to farmland bird declines? Links between soil penetrability and the abundance of yellow wagtails Motacilla flava in arable fields. Biological Conservation 141: 3116-3126.

Heneberg P. 2001. Size of sand grains as a significant factor affecting the nesting of bank swallows (Riparia riparia). Biologia 56: 205-210.

Heneberg P. 2004. Soil particle composition of Eurasian Kingfisher (Alcedo atthis) nest sites. Acta Zoologica Academia Scientiarium Hungaricae 50: 185-193.

Heneberg P. 2009. Soil penetrability as a key factor affecting the nesting of burrowing birds. Ecological Research 24: 453-459

Imboma TS, Nalianya N. 2007. The breeding success and seasonal distribution of the malachite kingfisher (Alcedo cristata) along the Nairobi River. Ostrich 78: 510.

Libois R, Laudelout A. 2004. Food niche segregation between the Malachite Kingfisher, Alcedo cristata, and the Pied Kingfisher, Ceryle rudis, at Lake Nokoue, Benin. Ostrich 75: 32-38.

Martin TE. 1987. Food as a limit on breeding birds: a life-history perspective. Annual Reviews in Ecology and Systematics 18: 453-487.

Monadjem A, Owen-Smith RN. 1994. Perch-site selection by three species of kingfishers. Ostrich 65: 342-343.

Richer de Forges A, Feller C, Jamagne M, Arrouays D. 2008. Perdus dans le triangle des textures. Étude et Gestion des Sol 15: 97-111.

Ricklefs RE. 1968. Patterns of growth in birds. Ibis 110: 419-451.

Peris S J, Rodriguez R. 1996. Some factors related to distribution by breeding Kingfisher (Alcedo atthis L.). Ekologia Polska 54: 31-38. 
Petersen AJ. 1955. The breeding cycle in the Bank Swallow. Wilson Bulletin 67: 235-286.

Sandmann-Funke S. 1972. Untersuchungen zur Anlage von Uferschwalbenkolonien in Abhängigkeit von Bodentypen. Abhandlungen aus dem Landesmuseum für Naturkunde zu Münster in Westfalen 34: 88-94.

Siikamäki P. 1998. Limitation of reproductive success by food availability and breeding time in pied flycatchers. Ecology 79: 1789-1796.

Yuan HW, Wang MK, Chang WL. 2006. Soil composition affects the nesting behavior of blue-tailed bee-eaters (Merops philippinus) on Kinmen Island. Ecological Research 21: 510-512.

Woodall PF. 1991. Morphometry, diet and habitat in the kingfishers (Aves: Alcedinidae). Journal of Zoology 223: 79-90. 
Appendix 1: Soil texture from 56 samples collected in banks with $(n=23)$ and without $(n=23)$ evidence of reproduction in the Malachite Kingfisher from the Kinshasa area

\begin{tabular}{|c|c|c|c|c|}
\hline Site & $\begin{array}{c}\text { Sand } \\
(\%)\end{array}$ & $\begin{array}{l}\text { Silt } \\
(\%)\end{array}$ & $\begin{array}{l}\text { Clay } \\
(\%)\end{array}$ & $\begin{array}{l}\text { Banks } \\
\text { status }\end{array}$ \\
\hline Bombo-Lumene & 90.6 & 5.9 & 3.5 & Occupied \\
\hline Kemi 1 (Lemba) & 92.6 & 4.9 & 2.5 & Occupied \\
\hline Kemi 2 (Lemba) & 92.6 & 4.9 & 2.5 & Occupied \\
\hline Kemi 3 (Lemba) & 91.8 & 5.1 & 2.7 & Occupied \\
\hline Kinkolé 1 (N'sele) & 68.9 & 13.1 & 18.2 & Occupied \\
\hline Kinkolé 2 (N’sele) & 66.2 & 14.6 & 18.9 & Occupied \\
\hline Kinkolé 3 (N’sele) & 66.2 & 14.6 & 18.9 & Occupied \\
\hline Kinkolé 4 (N'sele) & 66.2 & 14.6 & 18.9 & Occupied \\
\hline Mbankana 1 (Maluku) & 90.6 & 5.8 & 3.7 & Occupied \\
\hline Mbankana 2 (Maluku) & 90.6 & 5.8 & 3.7 & Occupied \\
\hline Monastère 1 (Mont-Nagfula) & 92.1 & 5.0 & 2.2 & Occupied \\
\hline Monastère 2 (Mont-Nagfula) & 92.2 & 5.1 & 2.1 & Occupied \\
\hline Monastère 3 (Mont-Nagfula) & 92.2 & 5.1 & 2.1 & Occupied \\
\hline Monastère 4 (Mont-Nagfula) & 92.2 & 5.1 & 2.1 & Occupied \\
\hline Monastère 5 (Mont-Nagfula) & 92.2 & 5.1 & 2.1 & Occupied \\
\hline Monastère 6 (Mont-Nagfula) & 92.2 & 5.1 & 2.1 & Occupied \\
\hline Monastère 7 (Mont-Nagfula) & 92.2 & 5.1 & 2.1 & Occupied \\
\hline Monastère 8 (Mont-Nagfula) & 92.2 & 5.1 & 2.1 & Occupied \\
\hline Monastère 9 (Mont-Nagfula) & 92.2 & 5.1 & 2.1 & Occupied \\
\hline Symphonies 1 (Ngaliema) & 73.1 & 17.8 & 7.8 & Occupied \\
\hline Symphonies 2 (Ngaliema) & 73.2 & 18.8 & 8.0 & Occupied \\
\hline Symphonies 3 (Ngaliema) & 73.2 & 18.8 & 8.0 & Occupied \\
\hline Symphonies 4 (Ngaliema) & 73.2 & 18.8 & 8.0 & Occupied \\
\hline Symphonies 5 Ngaliema) & 73.2 & 18.8 & 8.0 & Occupied \\
\hline Symphonies 6 (Ngaliema) & 73.5 & 18.3 & 7.7 & Occupied \\
\hline Symphonies 7 (Ngaliema) & 73.2 & 18.8 & 8.0 & Occupied \\
\hline Symphonies 8 (Ngaliema) & 73.2 & 18.8 & 8.0 & Occupied \\
\hline Symphonies 9 (Ngaliema) & 73.2 & 18.8 & 8.0 & Occupied \\
\hline Cecomaf 1 (N'djili) & 66.8 & 14.5 & 18.7 & Unoccupied \\
\hline Cecomaf 2 (N'djili) & 66.8 & 14.5 & 18.7 & Unoccupied \\
\hline Cecomaf 3 (N'djili) & 66.8 & 14.5 & 18.7 & Unoccupied \\
\hline Cecomaf 4 (N'djili) & 66.8 & 14.5 & 18.7 & Unoccupied \\
\hline Cecomaf 5 (N'djili) & 66.8 & 14.5 & 18.7 & Unoccupied \\
\hline Cecomaf 6 (N'djili) & 66.8 & 14.5 & 18.7 & Unoccupied \\
\hline Cogelos 1 (Mont-Ngafula) & 92.4 & 4.2 & 2.7 & Unoccupied \\
\hline Cogelos 2 (Mont-Ngafula) & 92.4 & 4.2 & 2.7 & Unoccupied \\
\hline Cogelos 3 (Mont-Ngafula) & 92.4 & 4.2 & 2.7 & Unoccupied \\
\hline Kimwenza 1 (Mont-Ngafula) & 90.6 & 3.1 & 6.3 & Unoccupied \\
\hline Kimwenza 2 (Mont-Ngafula) & 90.6 & 3.1 & 6.3 & Unoccupied \\
\hline Kimwenza 3 (Mont-Ngafula) & 90.6 & 3.1 & 6.3 & Unoccupied \\
\hline Kimwenza 4 (Mont-Ngafula) & 90.6 & 3.1 & 6.3 & Unoccupied \\
\hline Kimwenza 5 (Mont-Ngafula) & 90.6 & 3.1 & 6.3 & Unoccupied \\
\hline Kimwenza 6 (Mont-Ngafula) & 90.6 & 3.1 & 6.3 & Unoccupied \\
\hline Kimwenza 7 (Mont-Ngafula) & 90.6 & 3.1 & 6.3 & Unoccupied \\
\hline Kimwenza 8 (Mont-Ngafula) & 90.6 & 3.1 & 6.3 & Unoccupied \\
\hline Kimwenza 9 (Mont-Ngafula) & 90.6 & 3.1 & 6.3 & Unoccupied \\
\hline Kimwenza 10 (Mont-Ngafula) & 90.6 & 3.1 & 6.3 & Unoccupied \\
\hline Kinsuka 2 (Ngaliema) & 56.9 & 14.7 & 17.2 & Unoccupied \\
\hline Kinsuka 3 (Ngaliema) & 56.9 & 14.7 & 17.2 & Unoccupied \\
\hline Kinsuka 4 (Ngaliema) & 56.9 & 14.7 & 17.2 & Unoccupied \\
\hline Kinsuka 1 (Ngaliema) & 56.9 & 14.7 & 17.2 & Unoccupied \\
\hline Mimoza (Ngaliema) & 56.2 & 15.3 & 18.6 & Unoccupied \\
\hline Nganda yala (N'sele) & 66.0 & 10.7 & 12.3 & Unoccupied \\
\hline Nouvelle cite (Masina) & 66.8 & 14.5 & 18.7 & Unoccupied \\
\hline Quartier 1 (N'djili) & 66.8 & 14.5 & 18.7 & Unoccupied \\
\hline Quartier 7 (N'djili) & 66.8 & 14.5 & 18.7 & Unoccupied \\
\hline
\end{tabular}

